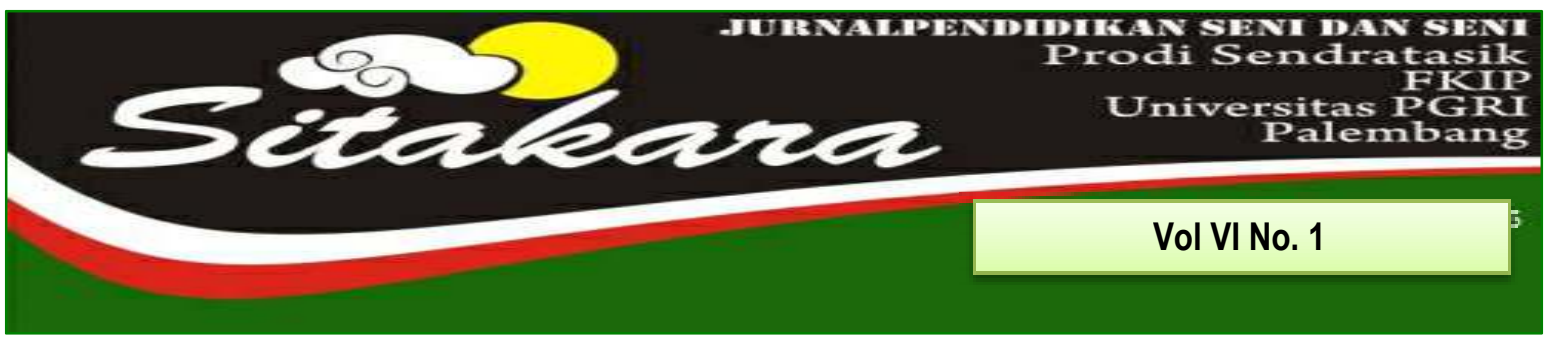

PERTUNJUKAN SOLIS MARIMBA DENGAN REPERTOAR THE VARIANTIONS ON THEME (FROM THE MALAY'S "PUCUK PISANG")

(Fery Herdianto)

BUKIT SIGUNTANG DALAM PENGEMBANGAN KONSEP RUANG KOREOGRAFI $\quad$ 13-26 LINGKUNGAN TARI

(Rully Rochayati, Eva Dina Chairunisa)

APLIKASI SIBELIUS SEBAGAI MEDIA PEMBELAJARAN DALAM MENULIS NOTASI MUSIK BERMAS

(Dedy Firmansyah \& Nugroho NAD)

PENGARUH MODEL PEMBELAJARAN EXPLICIT INSTRUCTION PADA 40-54 PEMBELAJARAN TARI DAERAH

(Treny Hera \& Efita Elvandari)

SIMBOLISASI ORNAMEN NAGA PADA PEMBATAS JALAN DI PALEMBANG (Decky Kunian \& A.Heryanto)

PENGARUH MODEL PEMBELAJARAN INSIDE-OUTSIDE-CIRCLE (IOC) TERHADAP WRITING SKILL DALAM TEKS MENULIS DRAMA DI SMP SETIA NEGARA PALEMBANG

(Sri Wahyu Indrawati \& Yuspar Uzer)

PEMANFAATAN TEKNOLOGI MULTIMEDIA DALAM PEMBELAJARAN MUSIK DI $79-87$ SMP N 1 PALEMBANG

(Novdaly Fillamenta \& Yuliza Aryani)

BENTUK PENYAJIAN ORKES GAMBUS SANGGAR MOZAIG PADA ACARA PERNIKAHAN ADAT ARAB PALEMBANG

(Auzy Madona Adoma)

PENINGKATAN KEMAMPUAN MEMBACA TEKS DRAMA DENGAN 100-111 MENGGUNAKAN METODE SPEED READING PADA PEMBELAJARAN BAHASA INDONESIA UNTUK SISWA SMPN 16 PALEMBANG (Wandiyo)

PELAKSANAAN EVALUASI PEMBELAJARAN SENI BUDAYA DI SMP 1 JEKULO 112-123 KUDUS PADA MASA PANDEMI COVID-19

M.Panji Wahyu Mukti \& Wahyu Lestari 
1. Naskah berbahasa Indonesia bertemakan Seni Budaya yang meliputi hasil penelitian pengajaran seni budaya, cabang seni, dan kebudayaan.

2. Naskah harus asli dan belum pernah dimuat dalam media lain. Naskah dapat berupa hasil penelitian perorangan atau kelompok.

3. Naskah ditulis dengan cara-cara yang sesuai dengan ketentuan penulisan artikel ilmiah menggunakan bahasa Indonesia yang baku, berupa ketikan, beserta soft line dalam CD-RW atau dengan mengirimkan email pada redaksi Jurnal SITARARA dengan alamat email: jurnalsitakarasendratasik@yahoo.com, spasi 1,5 jenis huruf Arrial Narrow ukuran 12, dengan panjang naskah antara 8-15 halaman pada kertas A4.

4. Artikel hasil penelitian memuat:

JUDUL

Nama Penulis

Abstrak

A. Pendahuluan

B. METODE PENELITIAN

C. HASIL DAN PEMBAHASAN

D. SIMPULAN
: XXX (HURUF KAPITAL)

: (disertai jabatan dan institusi)

: (Bahasa Indonesia yang memuat 100150 kata diikuti kata kunci, dengan jenis huruf Arrial Narrow dan ukuran huruf 11 spasi tunggal serta dicetak miring)

: (Memuat latar belakang masalah, tinjauan pustaka secara ringkas, masalah penelitian dan tujuan penelitian)

: (Berisi simpulan)

5. Artikel kajian konseptual memuat:

JUDUL

Nama Penulis

Abstrak

\section{: XXX (HURUF KAPITAL)}

: (disertai jabatan dan institusi)

: (Bahasa Indonesia yang memuat 100150 kata diikuti kata kunci, dengan jenis huruf Arrial Narrow dan ukuran huruf 11 serta dicetak miring)

PENDAHULUAN
: (Memuat latar belakang masalah, tinjauan pustaka secara ringkas, masalah penelitian dan tujuan penelitian) 
Sub Judul

Sub Judul

SIMPULAN

DAFTAR PUSTAKA
: Sesuai dengan kebutuhan (tanpa numbering)

: (Berisi simpulan dan saran)

: (Berisi pustaka yang dirujuk dalam uraian naskah

6. Referensi sumber dalam teks artikel ditulis dengan menggunakan side note, contoh: (Jalalluddin, 1991:79); (Taufik, 2005;350); (Hamid dan Madjid, 2011:43). Sementara penulisan daftar pustaka disusun dengan ketentuan. Nama Pengarang. Tahun Terbit. Judul (dicetak miring). Kota Terbit: Nama Penerbit. Contoh: Koentjaraningrat. 2010. Manusia dan Kebudayaan Di Indonesia. Jakarta: Djambatan.

Daftar pustaka hanya memuat pustaka/sumber yang dirujuk dalam uraian dan disusun menurut abjad, tanpa nomor urut.

7. Naskah yang dimuat akan disunting kembali oleh redaksi tanpa mengubah isinya.

8. Naskah yang ditolak (tidak bisa dimuat) akan dikirim kembali ke penulis dengan pemberitahuan tertulis dari redaksi atau alamat email.

9. Penulis yang naskahnya dimuat akan mendapatkan 1 (satu) majalah nomor yang bersangkutan.

10. Contact Person: Treny Hera (085357344704) dan Mainur (081373165553). 


\title{
SIMBOLISASI ORNAMEN NAGA PADA PEMBATAS JALAN DI PALEMBANG
}

\author{
Oleh: \\ Decky Kunian ${ }^{1}$ \\ A. Heryanto ${ }^{2}$ \\ (Dosen FKIP Universitas PGRI Palembang) \\ Email: deckykunian@gmail.com
}

\begin{abstract}
ABSTRAK
Naga dihadirkan dalam intisari kehidupan masyarakat Palembang yang dipercayai membawa unsur kebaikan dalam berkehidupannya. Semua diyakini karena memang telah berakar dan membudayanya pengetahuan dan pemahaman terhadap naga tersebut. Sehingga keberadaan naga sering dijumpai hingga saat ini termasuk pada pembatas jalan ditengah-tengah kota Palembang yang meyakini bahwa naga memiliki makna simbolis makhluk sebagai penyelamat dan penjaga bumi, sebagai lambang kesuburan karena menjaga keseimbangan air. Maka tidaklah heran jika naga yang sarat dengan arti simbolis yang kemudian masyarakat Palembang menerapkannya karena mengganggap naga sebagai lambang yang memiliki nilai-nilai magis, spiritual, kebaikan, perlambang kemakmuran, dan kebijaksanaan, serta naga sebagai sumber pembawa unsur kebaikan dalam kehidupan masyarakat Palembang.
\end{abstract}

Kata Kunci: Simbolisasi, Ornamen Naga.

\section{A. PENDAHULUAN}

Palembang merupakan ibu kota Provinsi Sumatera Selatan yang juga merupakan kota terbesar ke dua setelah Medan di Pulau Sumatera. Palembang merupakan daerah tingkat 1 dalam Provinsi Sumatera Selatan. Secara geografis terletak diantara $2^{\circ} 50^{\prime}$ lintang Selatan dan $104^{\circ}, 37^{\prime}-104^{\circ} 52^{\prime}$ bujur timur pada ketinggian rata-rata 12 meter diatas permukaan laut. Dengan luas wilayah 400,61 km2 yang secara administrasi terbagi atas 16 kecamatan dan 107 kelurahan. Palembang merupakan salah satu kota tertua di
Indonesia dengan dilatarbelakangi sejarah kerajaan Sriwijaya yang berkuasa di Asia Tenggara pada abad ke VII. Palembang terdapat sungai Musi yang berfungsi sebagai sarana transportasi dan perdagangan antar wilayah. Secara geografis Palembang sangat strategis sebagai daerah pemasok berbagai kebutuhan barang. Hal ini dapat dilihat melalui sejarah tua Palembang yang menjadi pintu masuk para pedagang dari wilayah lain, yang menjadikan kota ini sebagai kota akulturasi budaya. 
Terjadinya proses akulturasi, ada berbagai alasan berkaitan dengan siapakah individu-individu yang cepat atau lambat menerima akulturasi. Menurut Purwanto (2000: 187), tidak selalu sepenuhnya tepat bahwa orang muda lebih responsive dari pada orang tua. Cepat atau lambatnya seseorang menerima unsur-unsur kebudayaan lain, seyogyanya bukan hanya dikaitkan dengan jenis unsur-unsur kebudayaan asing, tetapi juga berbagai latar belakang yang melingkari diri seseorang dan kepentingan apa yang terkait.

Akulturasi itu sendiri merupakan proses sosial yang terjadi bila manusia dalam suatu masyarakat dengan suatu kebudayaan tertentu, dipengaruhi oleh unsur-unsur kebudayaan asing yang berbeda sifatnya.

Unsur-unsur kebudayaan asing tersebut lambat laun diakomodasi dan diintegrasikan ke dalam kebudayaan sendiri tanpa kehilangan kepribadian dan kebudayaan sendiri (Koentjaraningrat, 1990: 91). Artinya bahwa akulturasi terjadi apabila suatu kelompok manusia dengan suatu kebudayaan yang tertentu, dihadapkan unsur-unsur dari suatu kebudayaan asing yang berbeda sedemikian rupa, sehingga unsur-unsur kebudayaan asing itu dengan lambat laun diterima dan diolah ke dalam kebudayaan sendiri, tanpa menyebabkan hilangnya kepribadian kebudayaan itu sendiri.

Proses akulturasi di dalam sejarah kebudayaan Palembang, telah terjadi dalam masa-masa yang silam. Hal tersebut berakar baik dalam aktifitas perdagangan, pemerintahan, pernikahan antara dua ras yang berbeda, dan sebagainya, dimana unsur masingmasing kebudayaan saling menyusup. Proses migrasi, asimilasi, bilateral, hingga multilateral dapat mempermudahkan berlangsunganya akulturasi tersebut. Suatu proses akulturasi yang berjalan dengan baik, dapat menghasilkan intergrasi dari unsur-unsur kebudayaan asing dengan unsur-unsur kebudayaan sendiri dari masyarakat penerima. Dengan demikian, unsur-unsur kebudayaan asing tidak dirasakan lagi sebagai hal yang berasal dari luar oleh masyarakat Palembang, akan tetapi dianggap sebagai unsurunsur kebudayaan sendiri. Unsur-unsur asing yang diterima tersebut, tentunya terlebih dahulu mengalami proses pengolahan, sehingga bentuknya tidaklah asli lagi seperti semula yang 
tentunya semua berakar dari adanya akulturasi budaya Cina dan masuknya pengaruh Islam yang mengharamkan penggambaran makhluk hidup. Jika membandingkan keberadaan naga yang tidak terlepas dalam kebudayaan Palembang, semua tampak pada banyaknya ornamen naga yang menghiasi kota Palembang yang diyakini bukan hanya bernilai estetis tetapi juga memiliki makna simbolis, seperti yang pada pembatas jalan di kota Palembang.

\section{B. METODELOGI PENELITIAN}

Penelitian ini merupakan penelitian kualitatif yang tujuannya adalah ingin mengetahui bentuk dan makna simbolisasi naga pada pembatas jalan di Palembang, maka metode yang dapat digunakan adalah metode penelitian kualitatif deskriptif. Dimana metode-metode kualitatif memungkinkan kita memahami masyarakat tempat penelitian secara personal dan memandang mereka sebagaimana mereka sendiri menggunakan dunianya. Selain itu ciri dari penelitian kualitatif yaitu: (1) penelitian yang meneliti latar belakang obyek sesuai dengan kondisi yang wajar, (2) menyesuaikan diri dengan kenyataan ganda yag dijumpai dalam proses penelitian, (3) proses berbentuknya siklus dengan mengandalkan penelitian sebagai instrument utama, dan (4) menggunakan rancangan penelitian yang luwes, dalam arti memugkinkan penyempurnaan selama proses penelitian.

Untuk memperlancar penelitian dan agar dapat berjalan secara sistematis maka dibuat tahap-tahap penelitian yang meliputi, (1) tahap penentuan sasaran penelitian; (2) tahap pengumpulan data dan; (3) tahap pembahasan data. Sasaran penelitian ini adalah seluruh ornamen naga yang terdapat di jalan kota Palembang. Penelitian ditujukan untuk mengadakan identifikasi bentuk pola dan ornamennya dengan mengenali, menandai, membuat klasifikasi dan menginterpertasikannya. Analisis data yang digunakan dalam penelitian ini adalah Model analisis Miles dan Huberman (dalam Sugiyono, 2015:246) yang mencangkup tiga kegiatan yang bersamaan reduksi data, penyajian data dan penarikan kesimpulan.

\section{HASIL DAN PEMBAHASAN}

Perkembangan kebudayaan di Palembang dipengaruhi oleh 
kebudayaan asing, terutama Cina. Dengan masuknya pengaruh luar dari Cina tersebut maka memberikan corak tersendiri dalam kebudayaan Sumatera Selatan, khususnya Palembang hingga kini. Sehingga Palembangpun berkembang menjadi masyarakat yang multietnis dan multikultur. Banyaknya unsur kebudayaan yang mengadopsi dari sistem kepercayaan ataupun budaya dari negeri Tirai Bambu ini, seperti makanan, ornamen, dan sebagai salah contoh jelas lainnya seperti (masuknya corak Cina) yang terdapat pada ornamen naga pada pembatas jalan di Palembang.

Mitos merupakan sesuatu hal yang dipercayai oleh sebagian orang, biasa dipakai untuk menakut-nakuti, memberi peringatan, ataupun diceritakan secara berkelanjutan. Semua mitos yang ada di dunia, merupakan mitos yang telah ada sejak zaman nenek moyang, dikarenakan cerita yang terus bergulir, atau bisa saja sesuatu mitos berubah dikarenakan zaman yang terus berkembang. Bagi sebagian orang mitos merupakan sesuatu yang sudah jarang dipercaya, tapi masih juga ada yang percaya tentang mitos-mitos tertentu dan terus bergulir sampai sekarang, seperti mitos mengenai keberadaan naga yang diyakini masyarakat Palembang merupakan makhluk mitologi yang mengadopsi dari kebudayaan Cina.

Mengutip pendapat Marcel Danesi, yang menyatakan bahwa mitos adalah narasi yang karakter-karakter utamanya adalah para dewa, para pahlawan, dan makhluk mistis, plotnya berputar disekitar asal muasal bendabenda atau disekitar makna bendabenda, dan settingnya adalah dunia metafisika yang dilawankan dengan dunia nyata (2012: 167).

Konsep naga yang dituangkan dalam songket Palembang tentunya berdasarkan mitos dari naga itu sendiri yang mempunyai makna bagi masyarakat palembang baik dari satu kesatuan bentuknya yang memiliki unsur pembentuk tersendiri. Sependapaat dengan Ernst Cassier (dalam Marcel Danesi, 2012: 173) yang melihat mitos muncul dari respon emosional komunal terhadap alam seperti ketakutan akan guntur, petir, dan lain-lain. Dalam mitos, identitas dan nilai-nilai dasar kelompok diberi makna absolut. Sependapat dengan Levi Strauss (dalam AhimsaPutra, 2001: 94) bahwa jika memang mitos dipandang sebagai sesuatu yang 
bermakna, maka itu tidaklah terdapat pada unsur-unsurnya yang berdiri sendiri, yang terpisah satu dengan yang lain. Cara mengkombinasikan unsurunsur mitos inilah yang menjadi tempat keberadaan makna.

\section{Kepercayaan}

mendalam

sekumpulan masyarakat Palembang yang memang telah memiliki percampuran etnis Cina yang percaya akan hadirnya naga dapat disebut sebagai ekspresi identitas yang melekat dalam masyarakat Palembang. Jadi secara sadar atau tidak mitos naga yang sampai sekarang masih juga dipercayai merupakan mitos yang telah ada sedari dulu dan berkembang. Maka hal tersebut menjadi sesuatu yang dipercayai bersama karena mitos naga tidak hanya merupakan sebuah cerita, tapi juga dipercayai adanya, dan hal itu bisa jadi berubah sesuai zamannya.

Kepercayaan terhadap mitos naga akan terus ada, berbeda-beda dan terus berkembang, tidak hanya terjadi karena cerita yang turun temurun, tapi juga karena adanya perasaan yang terekspresi terhadap diri seseorang, yang terus menerus ditekan maka perasaan yang diekspresi tersebut dapat dijadikan sebuah kepercayaan. Mitos naga bisa saja merupakan keinginan yang secara tidak disadari oleh seseorang tapi pada akhirnya keinginan yang tidak biasa tersebut bisa saja terealisasikan dengan cara yang tidak terduga. Menurut Levi-Strauss pulalah mitos tidak hanya dilihat secara psikoanalisisnya saja, tapi juga dilihat dari segi sejarah atau apa yang menyebabkan mitos tersebut dapat terjadi. Naga tergolong dalam ornamen binatang atau makhluk imajinatif, Ornamen binatang untuk menyusun atau pembentukannya dapat dilakukan dengan cara meniru, menggayakan, mendistorsikan, atau mendeformasikan keseluruhan dan/atau sebagian organ tubuhnya (Guntur, 2004: 5-45).

Jadi bisa disimpulkan bahwa mitos naga dalam kebudayaan masyarakat Palembang adalah kepercayaan yang terjadi secara turun temurun pada masyarakat Palembang, dan bisa dikaitkan dengan sejarah yang terjadi sebelumnya dimulai dengan bercerita dari awal bagaimana mitos naga tersebut dapat tumbuh, berkembang dan dipercayai keberadaannya, dan juga merupakan suatu hasil ekspresi yang terjadi di alam bawah sadar masyarakat pedukungya 
(Palembang). Menurut Suparlan, kebudayaan dapat dideskripsikan sebagai makna dari benda, tindakan dan peristiwa dalam kehidupan sosial, dalam pandangan mereka yang menjadi pelakunya. Dalam perwujudannya, kebudayaan dapat dilihat dari tiga aspek, yaitu; (1) apa yang mereka lakukan; (2) apa yang mereka ketahui; (3) benda apa yang digunakan dalam kehidupan. Benda apa yang digunakan oleh para pendukung kebudayaan tersebut, dapat diberi makna (dalam Syarofie, 2012: 15).

Ketika suatu perasaan yang hadir, seperti ketakutan atau khawatir, dan berbagai rasa lain diekspresi di dalam diri seseorang maka akan tertanam rasa yang pada akhirnya menjadi suatu kepercayaan. Seperti halnya mitos naga yang terjadi secara turun menurun di dalam masyarakat Palembang, maka hal tersebut akan terus berkelanjutan dan dipercayai dari generasi ke generasi dan cerita tersebut akan tersimpan di alam bawah sadar.

Naga dihadirkan dalam intisari kehidupan masyarakat Palembang yang dipercayai membawa unsur kebaikan dalam berkehidupannya. Semua diyakini karena memang telah berakar dan membudayanya pengetahuan dan pemahaman terhadap naga tersebut. Sehingga keberadaan naga sering dijumpai hingga saat ini termasuk pada pembatas jalan ditengah-tengah kota Palembang (Wawancara; Adil, 2020).

Mengutip dari (Rustarmadi, 2012: 73) yang mengatakan bahwa naga memiliki makna simbolis makhluk sebagai penyelamat dan penjaga bumi, sebagai lambang kesuburan karena menjaga keseimbangan air. Senada dengan Rohidi mengatakan bahwa simbol merupakan komponen utama dalam kebudayaan. Sesungguhnya, setiap hal yang dilihat dan dialami manusia diolah menjadi serangkaian simbol yang dimengerti oleh manusia. Didalam simbol, termasuk simbol ekspresif, tersimpan berbagai makna antara lain berupa berbagai gagasan, abstraksi, pendirian, pertimbangan, hasrat, kepercayaan, serta pengalaman tertentu dalam betuk yang dipahami; didalam kesenian lebih tepat lagi dapat dihayati secara bersama. Oleh karena itu, kesenian, sebagaimana kebudayaan, dapat ditanggapi sebagai sistem-sistem simbol (2000: 30). Pemaparan diatas tidaklah heran jika naga yang sarat dengan arti simbolis yang kemudian masyarakat Palembang menerapkannya 
karena mengganggap naga sebagai lambang yang memiliki nilai-nilai magis, spiritual, kebaikan, perlambang kemakmuran, dan kebijaksanaan. Seperti yang peneliti paparkan berikut ini, yang menunjukkan bahwa adanya sistem kepercayaan tersebut yang meyakini akan kekuatan naga sebagai sumber pembawa unsur kebaikan dalam kehidupan masyrakat Palembang;

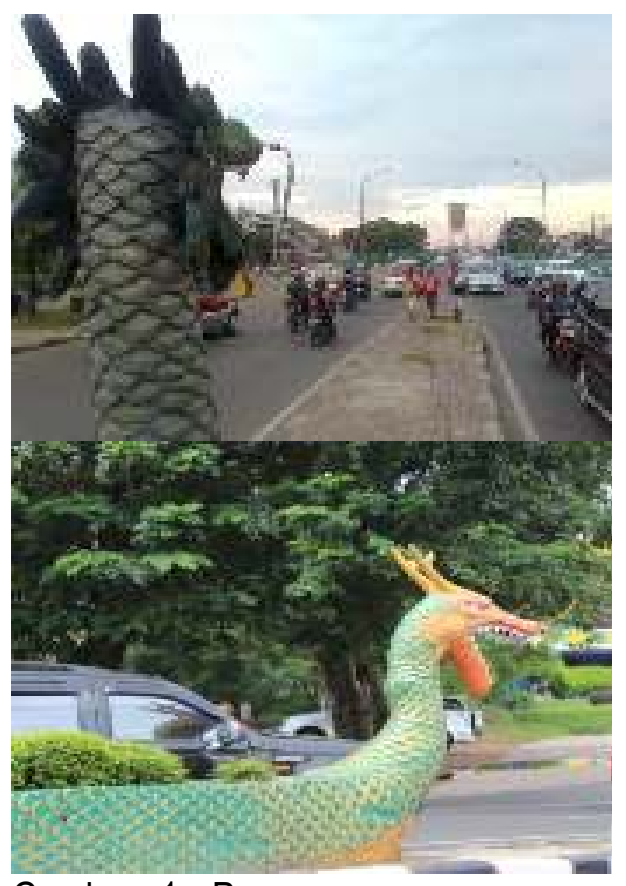

Gambar 1: Penerapan ornamen naga dipembatas jalan Palembang (foto: Decky, 2020)

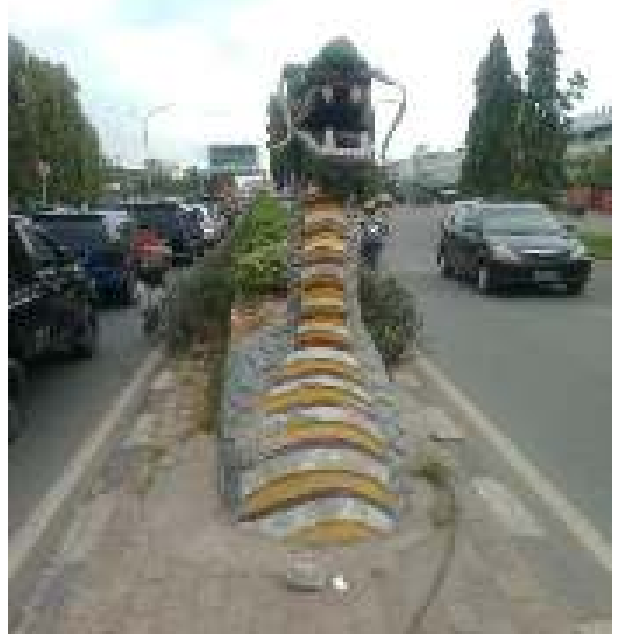

Gambar 2: penerapan ornamen naga dipembatas jalan Palembang (foto: Decky, 2020)

\section{SIMPULAN}

Simbolisasi ornamen naga dalam masyarakat Palembang merupakan kepercayaan yang terjadi secara turun temurun pada masyarakat Palembang, dan bisa dikaitkan dengan sejarah yang terjadi sebelumnya dimulai dengan bercerita dari awal bagaimana mitos naga tersebut dapat tumbuh, berkembang dan dipercayai keberadaannya, dan juga merupakan suatu hasil ekspresi yang terjadi di alam bawah sadar masyarakat pedukungya (Palembang). Naga dihadirkan dalam intisari kehidupan masyarakat Palembang yang dipercayai membawa unsur kebaikan dalam berkehidupannya. Semua diyakini karena memang telah 
berakar dan membudayanya pengetahuan dan pemahaman terhadap naga tersebut. Sehingga keberadaan naga sering dijumpai hingga saat ini termasuk pada pembatas jalan ditengahtengah kota Palembang yang meyakini bahwa naga memiliki makna simbolis makhluk sebagai penyelamat dan penjaga bumi, sebagai lambang kesuburan karena menjaga keseimbangan air. Maka tidaklah heran jika naga yang sarat dengan arti simbolis yang kemudian masyarakat Palembang menerapkannya karena mengganggap naga sebagai lambang yang memiliki nilai-nilai magis, spiritual, kebaikan, perlambang kemakmuran, dan kebijaksanaan, serta naga sebagai sumber pembawa unsur kebaikan dalam kehidupan masyarakat Palembang.

Ketika suatu perasaan yang hadir, seperti ketakutan atau khawatir, dan berbagai rasa lain diekspresi di dalam diri seseorang maka akan tertanam rasa yang pada akhirnya menjadi suatu kepercayaan. Seperti halnya mitos naga yang terjadi secara turun menurun di dalam masyarakat Palembang, maka hal tersebut akan terus berkelanjutan dan dipercayai dari generasi ke generasi dan cerita tersebut akan tersimpan di alam bawah sadar. Naga dihadirkan dalam intisari kehidupan masyarakat Palembang yang dipercayai membawa unsur kebaikan dalam berkehidupannya. Semua diyakini karena memang telah berakar dan membudayanya pengetahuan dan pemahaman terhadap naga tersebut. Sehingga keberadaan naga sering dijumpai hingga saat ini termasuk pada pembatas jalan ditengah-tengah kota Palembang dengan memaknai bahwa ornamen naga pada pembatas jalan tersebut sebagai lambang yang memiliki nilai-nilai magis, spiritual, kebaikan, perlambang kemakmuran, dan kebijaksanaan.

\section{DAFTAR PUSTAKA}

Marcel Danesi. Pesan, Tanda, dan Makna. Yogyakarta: Jalasutra. 2012.

Putra, Heddy Shri Ahimsa. Wacana Seni Dalam Antropologi Budaya Tekstual, Konstektual Dan Post-Modernistis. Dalam Putra, Heddy Shri Ahimsa., 2000. Ketika Orang Jawa Nyeni. Yogyakarta: Galang Press. 1998.

Strukturalisme Levi-strauss 'Mitos dan Karya Sastra'. Yogyakarta: KEPEL Press. 2006. 
Purwanto, Hari. 2000. Kebudayaan dan Lingkungan dalam Perspektif Antropologi. Yogyakarta: Pustaka Pelajar

Rustarmadi. Makna Simbolis Ragam Hias Pendapa Teras Candi Panataran. Journal: Seni Rupa Universitas Negeri Surabaya. 2012.

Sugiyono. 2015. Metode Penelitian Pendidikan (Pendekatan Kuantitatif,. Kualitatif dan $R \& D)$. Penerbit CV. Alfabeta: Bandung. 